\title{
Polycyclic Aromatic Hydrocarbons and Selected Heavy Metals in Some Oil Polluted Sites in Delta State Nigeria
}

\author{
Eucharia Oluchi Nwaichi1 ${ }^{*}$, Lawrence C. Chuku², Erhieyovwen Ighoavwogan² \\ ${ }^{1}$ Faculty of Engineering, The University of Nottingham, Nottingham, UK \\ ${ }^{2}$ Department of Biochemistry, Faculty of Science, University of Port Harcourt, Port Harcourt, Nigeria \\ Email: *nodullm@yahoo.com
}

How to cite this paper: Nwaichi, E.O., Chuku, L.C. and Ighoavwogan, E. (2016) Polycyclic Aromatic Hydrocarbons and Selected Heavy Metals in Some Oil Polluted Sites in Delta State Nigeria. Journal of Environmental Protection, 7, 1389-1410.

http://dx.doi.org/10.4236/jep.2016.710120

Received: July 13, 2016

Accepted: September 27, 2016

Published: September 30, 2016

Copyright $\odot 2016$ by authors and Scientific Research Publishing Inc. This work is licensed under the Creative Commons Attribution International License (CC BY 4.0).

http://creativecommons.org/licenses/by/4.0/

\begin{abstract}
Concentrations of selected heavy metals, nutrient elements and PAHs in farms and produce (cassava tubers and oil bean seeds) from 4-year-old crude oil impacted areas (Ekore and Uduvwoku) and a non-oil-impacted area (Okpe), all in Ughelli South Local Government Area, Delta State, Nigeria, were investigated to ascertain degree of risk posed. A random sampling design was chosen with three replications. Results obtained revealed significantly $(\mathrm{P}<0.05)$ elevated $\left(\mathrm{mg} \cdot \mathrm{kg}^{-1}\right) \mathrm{Cd}(0.240,0.140)$ and $\mathrm{Cr}$ $(1.327,3.122)$ in cassava samples for Ekore and Uduvwoku respectively in comparison to non-detectable amount for those of non-impacted source and exceeded set WHO limits of 0.1 and $0.05 \mathrm{mg} \cdot \mathrm{kg}^{-1}$ respectively. Although PAHs were low, oil spill increased available levels by factor of 2.5 and 5 for Ekore and Uduvwoku respectively. Again, Cd and $\mathrm{Cr}$ exceeded WHO limit for study impacted soils. Available N, $\mathrm{P}$ and $\mathrm{K}$ decreased (\%) by 56.1, 28.5 and 2.4 for Ekore and 82.9, 39.9 and 45.5 for Uduvwoku Cassava samples. Nutrient profiling in oil bean revealed \% reduction in avaliable N, P and $\mathrm{K}$ by 33.7, 47.7 and 57.9 and 28.9, 76.3 and 39.8 for Ekore and Uduvwoku samples respectively. For oil bean, $\mathrm{Cd}$ and $\mathrm{Cr}$ did not differ markedly between polluted samples but exceeded WHO limits. Other studied contaminants fell within limits. In soils, available N, P and $\mathrm{K}$ decreased (\%) by 39.6, 79.1 and 27.4 for Ekore and 53, 88.1 and 45.5 for Uduvwoku samples. Low pH of 5.3 and 5.7 in Ekore and Uduvwoku respectively may increase the leachability of $\mathrm{Cr}$ into groundwater. Biopersistent $\mathrm{Cd}$ and $\mathrm{Cr}$ were found to biomagnify up the food chain and may impair major processes. Although PAHs were relatively low, their \% composition was more of High Molecular Weight that was less readily biodegraded by indigenous microorganisms, and hence can persist in the environment as carcinogens.
\end{abstract}




\section{Keywords}

Biomagnification, Crude Oil Spill, Cassava, Oil Bean, Niger Delta, Carcinogens

\section{Introduction}

The emergence of oil as the world's leading fuel was partly due to its relative cleanliness but the enormous scale of the petroleum industry's operation has inevitably created a new set of difficult environmental problems as being experienced today in the Niger Delta region of Nigeria [1]-[3]. In the study of the socio-economic impact of oil pollution, Worgu [4] stated that crude oil exploration has had adverse environmental effect on soil, forests and water bodies. Oil spill is common fallout of oil exploration and exploitation in the Niger Delta region with an estimated total of over 7000 oil spill accidents reported over a 50-year period [5]. Presently, in Nigeria, oil spills regularly occur in the oil producing areas of the country, while gases are continually flared in these areas [6] [7]. With advanced technology in use in the oil industry, accidents should be less frequent, but this certainly has not completely eliminated accidents and vandalisation [8]. Consequently, the Niger Delta region, over the years, has witnessed massive oil-based environmental degradation and soil fertility loss [9], agricultural decline [10] [11], oil spillage and gas flare, fisheries decline and depletion of biodiversity [12]. Crude oil pollution exerts adverse effects on plants indirectly by making toxic minerals in the soil available to them [13]. Oil spills have also been observed to cause death of plants, and have been linked with blood contamination of people working at impacted sites [14]. Crude oil pollution also leads to deterioration of soil structure, loss of organic matter contents, and loss of soil mineral nutrients. It also exposes soil to leaching and erosion [15]. The enhanced levels of these pollutants are judged in terms of the degree of toxicity, the extent of exploitation of the pollutants, their application, concentration and consequent mobilization into the soil. The presence of these pollutants obviously has resulted to loss of soil fertility, poor crop yield and harmful implications on humans and the entire ecosystem [13]. One of the greatest problems associated with oil pollution is the constant exposure to high concentration of heavy metals from oil [16] and also polycyclic aromatic hydrocarbons (PAHs) in soils from oil polluted areas [17]. Heavy metal contamination of agricultural soils and crops in the vicinity of mining areas has been regarded as a major environmental concern [18]-[20]. The presence of polycyclic aromatic hydrocarbons (PAHs) in food is also a matter of concern that requires continuous monitoring. In recent years, a number of epidemiological studies have shown that a large proportion of human cancers are attributable, at least in part, to dietary factors [21]. Consequently, one of the main reasons for concern about the exposure of humans to environmental contaminants is the evidence that a number of these contaminants are potentially carcinogenic. With the myriads of industries located in the Niger Delta region, it is therefore a thing of interest to investigate the level of heavy metals and PAH distribution in crops grown around these areas. Food crops 
grown on contaminated soils take up heavy metals and polycyclic aromatic hydrocarbons and then accumulate them in their tissues. Animals that graze on such contaminated plants and or drink from polluted water bodies accumulate these pollutants in their tissues. Humans that consume heavy metal contaminated foods consequently suffer biochemical disorders [22]. This research aims to evaluate the levels of polycyclic aromatic hydrocarbons and selected heavy metals in crude oil polluted soils and major crops grown on such soils in Ughevwughe community. This will provide baseline information on the level of risk faced by the people living within that region and for clean-up design.

\section{Description of the Study Area}

The study was conducted in October 2014 at two different cultivated farmlands from Ekore and Uduvwoku in Ughevwughe community. Ughevwughe is an Urhobo community in Uhurie Sub-clan of Ughievwen kingdom (Plate 1) in Ughelli South Local Government Area, LGA Delta State Nigeria. The territory of Ughievwen to which Ughevwughe belongs is made up of about thirty-two villages before and even after the British came to the area. Ekore and Uduvwoku are oil spill affected clans in Ughevwughe while Okpe-Olomu, a non-oil impacted clan within same LGA was chosen as control. The immediate neighbours of Ughevwughe community are Ekrejegba and Ekakpamre to the North, Ighwrekan, Edjophe, Otujeremi and Agbowhiame to the South, Ighwrekeka and Usiephron to the West, while to the East, it shares border with Effurun-Otor and Olomu clan. The area lies wholly in the tropics and could be located roughly at 5 , $12 \mathrm{~N}$ and 5, 80E [23]. Ughevwughe community has no oil well. However, it has Shell Petroleum Development Company (SPDC) facilities, that is, oil pipelines which crisscrosses the village and land. In the year 2010, a major tragedy befell the community. An oil spill occurred on the SPDC Row Utorogu-UPS delivery line, $8 \mathrm{~km}$ from Utorogu flow station. The delivery line is $16^{\text {II }} \mathrm{T} / \mathrm{L}$ Utoro-UQCC Magnet-mark MP 4. The spill was a result of ruptured equipment which resulted to leakage of crude oil into streams, farmlands and environment of Ughevwughe community and other neighbouring communities such as Okpare-Olomu, Otor-Edo, all in the same local government area. The vegetation of the study area falls within the rainforest region of Nigeria. Evidence from the on-the spot assessment of the polluted sites, and inquiries made, shows that no attempt of remediation of the site has been carried out. The disaster affected several kilometres of wet lands and was said to have caused incalculable damage to economic and social lives.

\section{Materials and Methods}

Materials: Cassava tubers, African oil bean seeds, and soil samples from study locations.

Source: All samples were gotten from Ekore and Uduvwoku (oil spill impacted areas in Ughevwughe) and Okpe-Olomu (non-oil impacted area), all in Ughelli South Local Government Area, Delta State. 


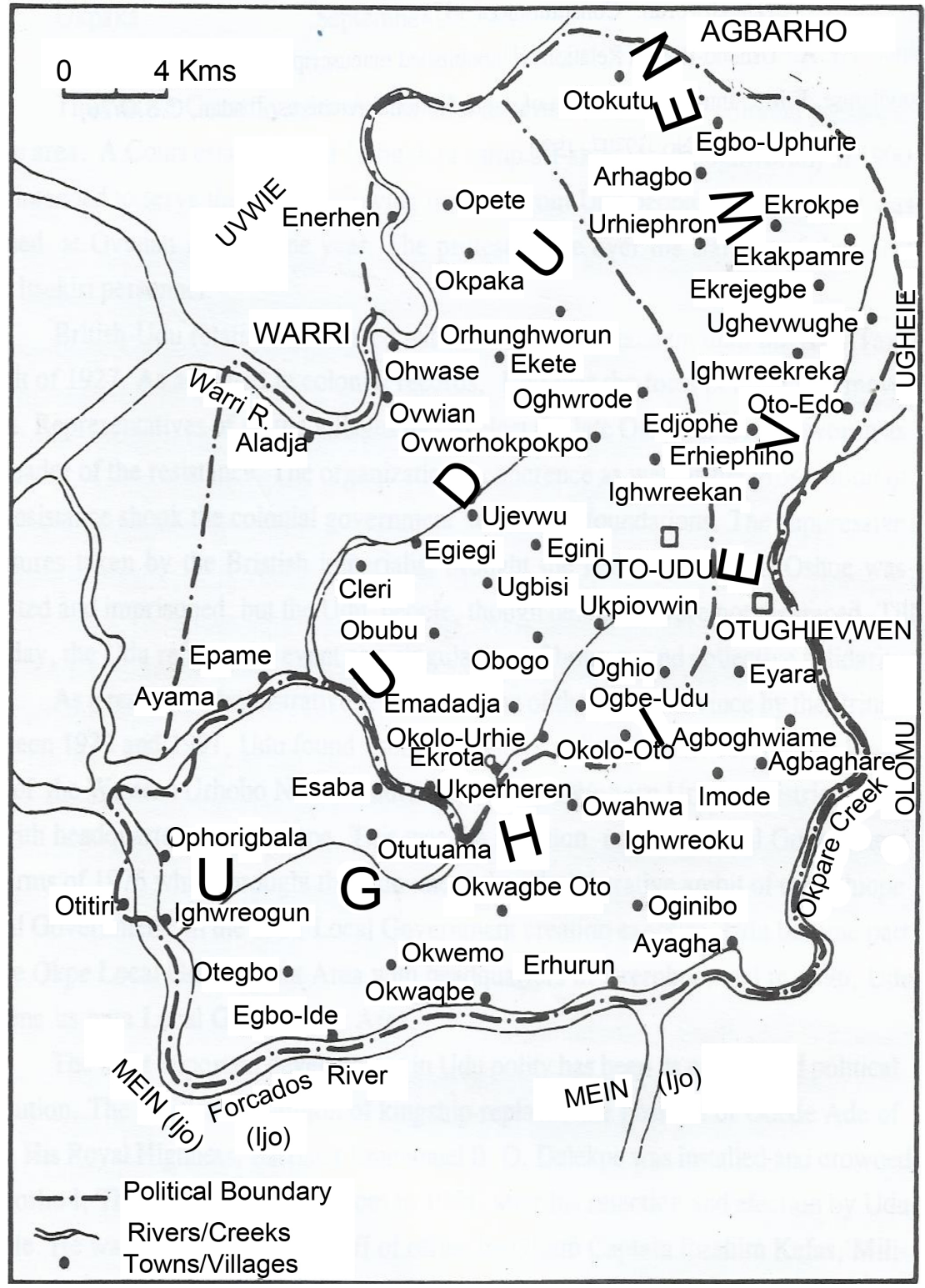

Plate 1. Map of Ughievwen showing the study area. $\bar{\gamma}$ Indicates study area.

\section{Sample Collection and Preservation}

An initial survey was carried out on the site prior to sample collection in order to ensure smooth sampling operations. The samples used in the analysis of this project were cassava tubers (Manihot esculenta, Crantz), edible seeds of African oil bean (Pentaclethra macrophylla, Benth) and surface soils collected from Udovwoku and Ekore quarters of Ughevwughe, and Okpe-Olomu, all in Ughelli-South Local Government Area, Delta state a South-southern state in Nigeria. A hand soil auger (Nickel-plated carbon steel, $3^{\text {II }}$ diameter) was used to collect soil samples in random replicates of three, at $0-20 \mathrm{~cm}$ depth, from two farmlands within the study area, approximately $200 \mathrm{me}-$ tres apart. Soil samples from the same site were bulked to form a composite sample. 
The samples were immediately on collection placed in sterilized, air-tight cellophane bags and labelled. The soil samples were put into appropriate containers and stored in a refrigerator at $4^{\circ} \mathrm{C}$ prior to laboratory analysis. Soil samples were also obtained in replicates of three from the control site (Okpe-Olomu) with the same geographical terrain as the study area for comparison. The auger was cleaned with water and rinsed with methanol after each sampling.

Samples of cassava tubers and African oil bean were collected randomly from all sites. The choice of the crops was based on their general growth pattern (luxuriant) on the contaminated soil, consumption rate and availability at the study area. For each crop, three replicates of samples were collected. The samples were put into well-labelled sterilized air-tight cellophane bags and stored at $4^{\circ} \mathrm{C}$ prior until required. Collected crops were identified by a taxonomist in the Department of Plant Biology and Biotechnology, University of Port Harcourt.

\section{Preparation of Samples for Analysis}

\subsection{Preparation of Soil Samples}

Soil samples were air-dried under room temperature to ensure constant weight, after which, they were homogenised using a ceramic mortar and pestle to obtain finer texture and to remove sticks, pebbles and rock particles. The air-dried soil samples were then sieved through a $2 \mathrm{~mm}$ polythene sieve. Particles larger than $2 \mathrm{~mm}$ mesh size were discarded.

\subsection{Preparation of Plant Samples}

Plant samples of the crops were gently washed under running tap water to remove adhered soil particles, and then with deionized water to remove any possible foliar contaminants such as pesticides, fertilizers, dust or mud. The crops were peeled and then cut into small pieces using a stainless knife, and oven-dried at $60^{\circ} \mathrm{C}$ for $24 \mathrm{hrs}$ to a constant mass. The dried tissues were stored in a moisture-free environment prior to further processing. The dried samples were then ground using a ceramic mortar and pestle to reduce the dried material to a suitable size for digestion and analysis.

\section{Sample Digestion and Analysis}

\subsection{Extraction and Analysis of Heavy Metals in Soil Samples}

The dishes were cleaned, dried and ignited, and covered at $500^{\circ} \mathrm{C}$ for 30 minutes in the furnace to inactivate or kill all persisting microbes. The dishes were cooled and covered in desiccators. They were weighed until a constant weight was obtained. A $5.0 \mathrm{~g}$ of the sieved air-dried soil samples was accurately put into the dish and ignited in a muffle furnace for 6 hours, opening the cover for escape of gases at $500^{\circ} \mathrm{C}$. This was checked periodically until complete ashing (a grey-white ash) was obtained. The ash samples were allowed to cool and $5 \mathrm{ml}$ of $10 \% \mathrm{HCl}$ was added to each sample to enhance dissolution, and $5 \mathrm{ml}$ of $10 \% \mathrm{HNO}_{3}$ was added thereafter and set on a water bath to dissolve 
completely. The solution was evaporated to near dryness on the water bath. On cooling to room temperature, the digest was filtered through Whatman No. 42 filter paper, into a clean, dry $50 \mathrm{ml}$ standard volumetric flask. Both the dish and the filter paper were washed into the flasks, made up to mark with deionized water [24]. The resultant solutions from the respective digestions were ready for metal analysis. The blank was also prepared following the same procedure.

\subsection{Extraction and Analysis of Heavy Metals in Cassava Tubers and Oil Bean Seeds}

A $5.0 \mathrm{~g}$ of each dried and crushed plant sample was accurately weighed (for wet digestion) into dish. This was burnt slightly for 6 hours, opening the cover for escape of gases at $500^{\circ} \mathrm{C}$. It was checked periodically until a grey-white ash was obtained. The ash samples were allowed to cool and $5 \mathrm{ml}$ of $10 \% \mathrm{HCl}$ was added to each sample to facilitate dissolution, and $5 \mathrm{ml}$ of $10 \% \mathrm{HNO}_{3}$ was added thereafter, and set on a water bath to dissolve completely. The digest was allowed to cool to room temperature and filtered through Whatman No. 42 filter paper, into a clean, dry $50 \mathrm{ml}$ standard volumetric flask. Both the dish and the filter paper were washed into the flasks, and marked up with deionized water [24]. The resultant solutions from the respective digestions and blank, prepared following the same procedure, were used for analysis for $\mathrm{Cd}, \mathrm{Zn}, \mathrm{Ni}, \mathrm{Cu}$ and Cr using GBC-Avanta PM SN A6600 Atomic Absorption Spectrophotometer. Matrix matching, standard addition and background correction were used to overcome interference. After every determination, the blanks and certified reference materials were also run to determine the precision and instrumental uncertainty. The percent recoveries of metals from the certified reference material were $93.2 \%, 95 \%, 89 \%, 85 \%$ and $96 \%$ for $\mathrm{Cd}, \mathrm{Zn}, \mathrm{Ni}, \mathrm{Cu}$ and $\mathrm{Cr}$ respectively.

\subsection{Determination of PAHs}

\subsubsection{Principle}

The samples were extracted with dichloromethane (DCM) and subjected to gas chromatographic analysis (HP Gas Chromatograph 5890 Series II).

\subsubsection{Extraction}

Two grams of samples were weighed into a clean extraction container ( $50 \mathrm{ml}$ beaker) and $10 \mathrm{ml}$ of extraction solvent (dichloromethane) was added into the samples, mixed thoroughly, and allowed to settle for 5 minutes. The mixture was carefully filtered into a clean solvent rinsed extraction bottle using filter paper fitted into a Buchner funnel. The extracts were concentrated to $2 \mathrm{ml}$ (using a water bath regulated at $35^{\circ} \mathrm{C}$ ) and then transferred for clean-up/separation.

\subsubsection{Clean Up/Separation}

One centimetre of moderately packed glass wool was placed at the bottom of $10 \mathrm{~mm} \mathrm{ID} \times$ 250 Loup chromatographic column. Slurry made from $2 \mathrm{~g}$ activated silica in $10 \mathrm{ml}$ methylene chloride was prepared and placed into the chromatographic column. To the top 
of the column was added 0.5 centimetre of sodium sulphate. The column was rinsed with additional $10 \mathrm{ml}$ of methylene chloride. The column was pre-eluted with $20 \mathrm{ml}$ of dichloromethane. This was allowed to flow through the column at the rate of about 2 minutes until the liquid in the column was just above the sulphate layer. Immediately, $1 \mathrm{ml}$ of the extracted sample was transferred into the column. The extraction bottle was rinsed with $1 \mathrm{ml}$ of dichloromethane and added to the column as well. The stop-cork of the column was opened and the eluent/extract was collected with a $10 \mathrm{ml}$ graduated cylinder. Just prior to exposure of the sodium sulphate layer to air, dichloromethane was added to the column in $1-2 \mathrm{ml}$ increments. Accurately measured volume of $8-10$ $\mathrm{ml}$ of the eluant was collected and labelled aromatics [25].

\subsubsection{Gas Chromatographic Analysis}

The concentrated aromatic fractions were transferred into labelled glass vials with Teflon rubber crimp caps for gas chromatographic analysis. One micro litre of the concentrated sample was injected by means of a hypodermic syringe through a rubber septum into the column. Separation occurs as the constituents of the vapour partition between the gas and liquid phases and oven temperature was programmed from $60^{\circ} \mathrm{C}$ to $180^{\circ} \mathrm{C}$. The sample was automatically detected as it emerges from the column at a constant flow rate by the FID detector whose response is dependent upon the composition of the vapour.

\subsubsection{Statistical Analysis}

The results were expressed as mean \pm standard error of the mean (SEM). All the data obtained were subjected to one-way ANOVA, using computer aided SPSS package (version 17.0).

\subsubsection{Quality Control}

Analytically, quality control measures (operation of all instruments in accordance with operating instructions as supplied by manufacturers, unless otherwise specified in the work plan; proper documentation of equipment checkout and calibration activities prior to sampling operations) and recovery study ranging from $92 \%-99 \%$ were carried out. Safety was generally carefully handled by using appropriate sampling equipment, containers and preservation method to avoid contamination of samples. All glass wares for metal analysis were previously soaked in $14 \% \mathrm{HNO}_{3}$ for 24 hours. All reagents used were of analytical grade and reagent blank determinations were used to correct errors. Multiplicity of samples for each determination ensured reproducibility of data.

\section{Results and Discussion}

Metals are persistent pollutants that can be biomagnified in the food chain becoming an integral part of life and thus increasingly dangerous to human beings and wildlife. Cadmium, Zinc, Nickel, Chromium and Copper levels were investigated. Cadmium levels in both soils and crop samples from the oil impacted sites were considered elevated (Table 1) in this study. The results showed that Cd levels in soils from Ekore and 
Table 1. Mean concentrations of some metals $\left(\mathrm{mg}^{\mathrm{kg}}{ }^{-1}\right)$ in study samples.

\begin{tabular}{|c|c|c|c|}
\hline \multirow{2}{*}{ Contaminants } & \multicolumn{3}{|c|}{ Amount in soil } \\
\hline & Okpe & Ekore & Uduvwoku \\
\hline $\mathrm{Cd}$ & $0.001 \pm 0.000^{\mathrm{a}}$ & $0.201 \pm 0.001^{c}$ & $0.110 \pm 0.000^{c}$ \\
\hline $\mathrm{Ni}$ & $1.010 \pm 0.176^{\mathrm{a}}$ & $2.077 \pm 0.003^{\mathrm{b}}$ & $1.263 \pm 0.176^{\mathrm{c}}$ \\
\hline $\mathrm{Cu}$ & $0.747 \pm 0.007^{\mathrm{b}}$ & $1.050 \pm 0.012^{\mathrm{a}}$ & $0.853 \pm 0.012^{\mathrm{a}}$ \\
\hline $\mathrm{Cr}$ & $0.003 \pm 0.000^{c}$ & $3.307 \pm 0.023^{\mathrm{a}}$ & $4.200 \pm 0.025^{\mathrm{b}}$ \\
\hline \multirow[t]{3}{*}{$\mathrm{Zn}$} & $2.113 \pm 0.026^{\mathrm{a}}$ & $0.907 \pm 0.009^{\mathrm{b}}$ & $0.477 \pm 0.012^{c}$ \\
\hline & \multicolumn{3}{|c|}{ Amount in Cassava tuber } \\
\hline & Okpe & Ekore & Uduvwoku \\
\hline $\mathrm{Cd}$ & $\mathrm{BDL}$ & $0.240 \pm 0.009^{\mathrm{b}}$ & $0.140 \pm 0.006^{\mathrm{b}}$ \\
\hline $\mathrm{Ni}$ & $1.963 \pm 0.024^{c}$ & $2.670 \pm 0.210^{\mathrm{b}}$ & $2.230 \pm 0.041^{\mathrm{a}}$ \\
\hline $\mathrm{Cu}$ & $1.283 \pm 0.009^{\mathrm{a}}$ & $3.010 \pm 0.000^{\mathrm{b}}$ & $3.023 \pm 0.009^{c}$ \\
\hline $\mathrm{Cr}$ & $\mathrm{BDL}$ & $1.327 \pm 0.020^{\mathrm{b}}$ & $3.122 \pm 0.688^{c}$ \\
\hline \multirow[t]{3}{*}{$\mathrm{Zn}$} & $4.797 \pm 0.026^{\mathrm{a}}$ & $6.433 \pm 0.078^{b}$ & $7.850 \pm 0.10^{\mathrm{b}}$ \\
\hline & \multicolumn{3}{|c|}{ Amount in oil bean seed } \\
\hline & Okpe & Ekore & Uduvwoku \\
\hline $\mathrm{Cd}$ & $0.093 \pm 0.003^{\mathrm{a}}$ & $0.137 \pm 0.003^{\mathrm{b}}$ & $0.413 \pm 0.009^{b}$ \\
\hline $\mathrm{Ni}$ & $5.593 \pm 0.038^{\mathrm{a}}$ & $2.617 \pm 0.018^{\mathrm{a}}$ & $2.480 \pm 0.017^{\mathrm{a}}$ \\
\hline $\mathrm{Cu}$ & $0.083 \pm 0.024^{c}$ & $0.330 \pm 0.252^{\mathrm{b}}$ & $3.257 \pm 0.013^{\mathrm{a}}$ \\
\hline $\mathrm{Cr}$ & $0.056 \pm 0.030^{\mathrm{b}}$ & $2.543 \pm 0.033^{\mathrm{a}}$ & $3.217 \pm 0.040^{\mathrm{a}}$ \\
\hline $\mathrm{Zn}$ & $0.243 \pm 0.020^{\mathrm{a}}$ & $1.683 \pm 0.030^{c}$ & $2.250 \pm 0.040^{\mathrm{b}}$ \\
\hline
\end{tabular}

Values (mean \pm S.E.M), $n=3$. Means in the same row bearing the same superscript letters are not significantly different at $95 \%$ level.

Uduvwoku (oil impacted sites) were significantly higher than Cadmium levels from Okpe (Control site) as shown in Table 1 and exceeded WHO limit of $0.10 \mathrm{mg} \cdot \mathrm{kg}^{-1}$ [26]. Similarly observed Cd levels in Cassava and Oil bean food samples exceeded tolerable weekly intake (TWI) values of $0.003 \mathrm{mg} \cdot \mathrm{kg}^{-1}$ and $0.007 \mu \mathrm{g} \cdot \mathrm{kg}^{-1}$ set by European Food Safety Authority and Joint FAO/WHO Expert Committee on Food Additives respectively as reported by EFSA [27]. Oil bean samples harvested from control site gave mean value $\left(0.093 \mathrm{mg} \cdot \mathrm{kg}^{-1}\right.$ exceeding reported TWI levels reported by EFSA [27] and may implicate Oil bean meal at bioconcentration of Cd. Cadmium is a non-essential element that negatively affects plant growth and development and is regarded as an extremely significant pollutant due to its high toxicity and large solubility in water as reported by Pinto et al. [28] and Lichtfouse [29]. Observed chlorosis, leaf rolls and stunting in this study were also reported as main symptoms of cadmium toxicity in plants [30].

Cadmium is regarded as a commutative toxin because of the human body's ability to excrete just $0.001 \%$ of the amount ingested in a day and chronic exposures result in kidney damage, bone deformities and cardiovascular problems [31]. Human diseases 
have resulted from consumption of Cd contaminated foods [32] as Alloway [33] described its greater mobility and and hence availability to plants in relation to their preferential binding to carbonates. The average biological half-life of $\mathrm{Cd}$, another accumulation poison similar to lead, has been estimated to be about 18 years [34]. Biochemically, Cd has been reported by Wolfgang and Jean-Marc [35] to act as a catalyst in forming reactive oxygen species; increasing lipid peroxidation and additionally depleting antioxidants, glutathione and protein-bound sulfhydryl groups. They also reported promotion of the production of inflammatory cytokines under Cd influence and hence the need for more caution. Overall, the threat heavy metals pose to human and animal health is aggravated by their low environmental mobility, even under higher precipitations, and their long term persistence in the environment [36]-[38]. Observed elevated levels in test areas may suggest that populations feeding on oil bean from these areas may be at a higher risk of Cd toxicity. The accumulation in the system may lead to acute $\mathrm{Cd}$ poisoning which includes high blood pressure, kidney damage, destruction of testicular tissue and destruction of red blood cells [39].

The mean concentrations of chromium showed higher accumulations in samples from test sites in relation to control samples with values $0.003 \pm 0.000 \mathrm{mg} \cdot \mathrm{kg}^{-1}, 3.307 \pm$ $0.023 \mathrm{mg} \cdot \mathrm{kg}^{-1}$ and $4.200 \pm 0.025 \mathrm{mg} \cdot \mathrm{kg}^{-1}$ for Okpe, Ekore and Uduvwoku respectively. These values fell above the WHO permissible limit of $0.05 \mathrm{mg} \cdot \mathrm{kg}^{-1}$ (WHO, 1985). Soil Cr values were also higher than the critical level of $0.02 \mathrm{mg} \cdot \mathrm{kg}^{-1}$ reported by Anderson et al. (1973). As observed with Cd (Table 1), bioconcentration of available Cr were higher in Oil bean samples even in control samples. Higher levels of Chromium in plants could cause toxicities in human. The permissible limit set by FAO/WHO [40] in edible plants was $0.02 \mathrm{ppm}$. Chromium has no verified biological role and has been classified as non-essential to mammals [41]. Chromium (VI) is toxic. Acute toxic effects occur when breathing very high levels of chromium (VI) in air, which can damage and irritate the nose, lungs, stomach and intestines [42]. Ingesting very large amounts of chromium can cause stomach upsets and ulcers, convulsions, kidney and liver damage, and even death [43].

Observed $\mathrm{Zn}$ levels in study soils were relatively lower than the WHO standard of $100 \mathrm{mg} \cdot \mathrm{kg}^{-1}$ [26]. Zinc concentrations was higher in the food samples from the oil impacted sites. The major sources of zinc in this site is probably the attrition of lubricating oils which zinc is found as part of many additives as zinc dithiophosphates. Zinc is essential to plants and animals in very low concentrations by serving as components of enzymes, structural proteins, pigments and also helping to maintain the ionic balance of cells [44]. Even though zinc is an essential requirement for a healthy body, excess zinc above $25 \mathrm{mg} \cdot \mathrm{kg}^{-1}$ can be harmful, and may cause zinc toxicity.

The observed levels of Copper and Nickel in all soil samples were relatively lower than WHO limits of $10 \mathrm{mg} \cdot \mathrm{kg}^{-1}$ and $10 \mathrm{mg} \cdot \mathrm{kg}^{-1}$ [26] respectively. High doses of copper, above the recommended daily allowance for dietary copper which is $2.5 \mathrm{mg} \cdot \mathrm{kg}^{-1}$ [45], are associated with anaemia, liver and kidney damage as well as irritation of both stomach and intestine [46]. High levels of copper above normal range of $5.00-20.00$ 
$\mathrm{mg} \cdot \mathrm{kg}^{-1}$ [47] required for plant growth caused grey node symptoms on plants grown on agricultural soils with excess amount of copper.

Nickel was higher in cassava and soil samples from the crude oil contaminated areas except for oil bean samples where that of Okpe (control) accumulated higher. This may be due to accumulation of heavy metals from other sources e.g. the use of fertilizers, waste dumpsites etc. [48].

Crude oil adversely affects the soil ecosystem through adsorption to soil particles, provision of an excess carbon that might be unavailable for microbial use and an induction of a limitation of soil nitrogen and phosphorus [49]. The effects of crude oil pollution on the properties of soil have been the subjects of many studies. Okolo et al. [50] reported that any contact of soil with crude oil results in damage to soil microorganisms and plants while Onuoha et al. [51] among others have shown that crude oil pollution prevents oxygen exchange between the soil and the atmosphere due to hydrophobic properties of oil. Significant delayed and decreased rate of crop germination were reported by Nwaichi and Wegwu [52].

The level of nitrates was $82.500 \mathrm{mg} \cdot \mathrm{kg}^{-1}$ dry weight in control Okpe (control site), $36.200 \mathrm{mg} \cdot \mathrm{kg}^{-1}$ dry weight in Ekore and $14.100 \mathrm{mg} \cdot \mathrm{kg}^{-1}$ dry weight in Uduvwoku for cassava samples (Table 2). This implies that crude oil spill drastically reduced soil nitrate contents of the polluted sites compared to control site at both soil depths. Oil contamination of soil has been shown to limit normal diffusion processes thereby reducing the availability of the level of some nutrients in the soil [53]. Evaluating NPK soil fertility, organic form of Nitrogen Nitrate Nitrogen was moderate for control (Okpe) site and low [54] for test (Ekore and Uduvwoku) sites in this study. However, soil concentrations of $\mathrm{NO}_{3}-\mathrm{N}$ depend upon the biological activity and may fluctuate with changes in soil temperature, soil moisture, and other conditions. Considering plant growth, physiology and carbohydrate content, $\mathrm{N}$ tops the needed nutrient list. A nitrate nitrogen level of $30 \mathrm{ppm}$ is considered sufficient during the active growing season for most plants [55]. Ammonium nitrogen concentrations fell below 2 - 10 ppm reported as common by Fulton et al. [54] for test sites. They reported that ammonium nitrogen does not usually accumulate in soil because conditions such as soil temperature and moisture suitable for tree growth are also ideal for conversion of $\mathrm{NH}_{4}-\mathrm{N}$ to $\mathrm{NO}_{3}-\mathrm{N}$. Higher nitrogen level in the control samples in comparison with the polluted areas could be as a result of fewer disturbances in activities of nitrogen-fixing bacteria and other microorganisms associated with the decomposition of organic matters, which might be inactivated or greatly distressed in the polluted sites. The reduction in the concentration of $\mathrm{NO}_{3}-\mathrm{N}$ in the contaminated sites suggests that the process of nitrification might have reduced following the incidence of oil spillage. According to Odu et al. [56], oil degrading or hydrocarbon-utilizing microbes such as Azobacter spp normally become abundant while nitrifying bacteria such as Nitrosomonas spp become reduced in number. This probably explains the relatively lower values of $\mathrm{NO}_{3}-\mathrm{N}$ obtained for the contaminated soils. Jobson et al. [57] had earlier reported that oil spills on land resulted in an imbalance in the carbon:nitrogen ratio which, if greater than 17:1 in soils resulted 
Table 2. Mean concentrations of nutrient parameters $\left(\mathrm{mg} \cdot \mathrm{kg}^{-1}\right)$ in study samples.

\begin{tabular}{|c|c|c|c|}
\hline \multirow{2}{*}{ Nutrients } & \multicolumn{3}{|c|}{ Amount in soil } \\
\hline & Okpe & Ekore & Uduvwoku \\
\hline $\mathrm{NO}_{3}-\mathrm{N}$ & $20.670 \pm 0.880^{\mathrm{a}}$ & $9.880 \pm 0.080^{\mathrm{b}}$ & $7.690 \pm 0.040^{\mathrm{b}}$ \\
\hline $\mathrm{NH}_{4}-\mathrm{N}$ & $3.274 \pm 0.340^{\mathrm{a}}$ & $1.066 \pm 0.066^{\mathrm{b}}$ & $0.734 \pm 0.0666^{\mathrm{b}}$ \\
\hline $\mathrm{PO}_{4}-\mathrm{P}$ & $20.000 \pm 0.600^{\mathrm{a}}$ & $4.300 \pm 0.300^{\mathrm{b}}$ & $2.300 \pm 0.300^{c}$ \\
\hline \multirow[t]{3}{*}{$\mathrm{K}$} & $156.600 \pm 7.209^{\mathrm{a}}$ & $99.246 \pm 0.046^{\mathrm{b}}$ & $74.440 \pm 0.003^{\mathrm{c}}$ \\
\hline & \multicolumn{3}{|c|}{ Amount in Cassava tuber } \\
\hline & Okpe & Ekore & Uduvwoku \\
\hline $\mathrm{NO}_{3}-\mathrm{N}$ & $82.500 \pm 0.981^{\mathrm{a}}$ & $36.200 \pm 0.529^{\mathrm{b}}$ & $14.100 \pm 0.173^{\mathrm{b}}$ \\
\hline $\mathrm{NH}_{4}-\mathrm{N}$ & $18.636 \pm 0.222^{\mathrm{a}}$ & $8.177 \pm 0.118^{\mathrm{c}}$ & $3.187 \pm 0.038^{\mathrm{b}}$ \\
\hline $\mathrm{PO}_{4}-\mathrm{P}$ & $1.077 \pm 0.023^{c}$ & $0.770 \pm 0.017^{\mathrm{a}}$ & $0.647 \pm 0.009^{b}$ \\
\hline \multirow[t]{3}{*}{$\mathrm{K}$} & $6455.700 \pm 9.241^{\mathrm{a}}$ & $6301.800 \pm 6.535^{\mathrm{b}}$ & $3515.700 \pm 0.688$ \\
\hline & \multicolumn{3}{|c|}{ Amount in oil bean seed } \\
\hline & Okpe & Ekore & Uduvwoku \\
\hline $\mathrm{NO}_{3}-\mathrm{N}$ & $145.830 \pm 1.975^{\mathrm{a}}$ & $96.433 \pm 1.302^{\mathrm{b}}$ & $103.760 \pm 1.729^{\mathrm{c}}$ \\
\hline $\mathrm{NH}_{4}-\mathrm{N}$ & $32.943 \pm 0.439^{\mathrm{a}}$ & $21.783 \pm 0.292^{\mathrm{b}}$ & $23.440 \pm 0.363^{c}$ \\
\hline $\mathrm{PO}_{4}-\mathrm{P}$ & $0.737 \pm 0.008^{\mathrm{a}}$ & $0.563 \pm 0.008^{\mathrm{b}}$ & $0.263 \pm 0.008^{\mathrm{b}}$ \\
\hline $\mathrm{K}$ & $3387.300 \pm 7.458^{\mathrm{a}}$ & $2040.200 \pm 9.325^{\mathrm{b}}$ & $1425.900 \pm 3.764$ \\
\hline
\end{tabular}

Values (mean \pm S.E.M), $n=3$. Means in the same row bearing the same superscript letters are not significantly different at $95 \%$ level.

in net mobilization of nutrients by microbes leading to loss of soil fertility. Increase in organic carbon is directly proportional to the increase of crude oil addition to soil. The high $\mathrm{C} / \mathrm{N}$ ratios leading to immobilization of soil nitrates coupled with the environment brought about by the oil pollution, accounted for low level of $\mathrm{NO}_{3}-\mathrm{N}$ in the oil contaminated soil.

Bray P1 method adopted gave marginal fertility in recorded ortho-phosphate level for control and low $(<20 \mathrm{ppm})$ values for test sites. This means that phosphorus availability has been significantly impaired with crude oil spill and poses a growth limiting factor. Also, dry and compacted crude oil spill soils at test sites may have hampered the release of both of Phosphorus. Since soil tests suggested low phosphorus fertility, the possibility of a deficiency was confirmed with plant tissue testing. Soil phosphate levels gave $2.300 \pm 0.300 \mathrm{mg} \cdot \mathrm{kg}^{-1}$ in Uduvwoku, $4.300 \pm 0.300 \mathrm{mg} \cdot \mathrm{kg}^{-1}$ in Ekore and $20.000 \pm$ $0.600 \mathrm{mg} \cdot \mathrm{kg}^{-1}$ in control site (Table 2). Lower values were also recorded in studied food samples. The reduction in the extractible phosphorus in the crude oil contaminated areas is probably due to high $\mathrm{C} / \mathrm{P}$ ratio resulting from the crude oil soil addition. The microorganisms which attack the hydrocarbons would immobilize the inorganic phosphorus in the soil, thus bringing about a reduction in extractible phosphorus [58]. This is in agreement with earlier findings of Udo [59].

Extractable Potassium levels in test sites fell within 75 - 150 ppm classified as low by Fulton et al. [54]. Although control site gave moderate amount, it signals future defi- 
ciencies ranking in the lower limit of recommended medium range in agricultural soils. Soil Potassium levels accumulated higher in control samples than in oil contaminated samples with values $74.440 \pm 0.003 \mathrm{mg} \cdot \mathrm{kg}^{-1}$ for Uduvwoku, $99.246 \pm 0.046 \mathrm{mg} \cdot \mathrm{kg}^{-1}$ for Ekore and $156.600 \pm 7.209 \mathrm{mg} \cdot \mathrm{kg}^{-1}$ dry weight for control site (Table 2). For cassava samples, potassium levels gave $3515.700 \pm 0.688 \mathrm{mg} \cdot \mathrm{kg}^{-1}$ for Uduvwoku, $6300.800 \pm$ $6.535 \mathrm{mg} \cdot \mathrm{kg}^{-1}$ for Ekore and $6455.700 \pm 9.241 \mathrm{mg} \cdot \mathrm{kg}^{-1}$ for control samples. In oil bean samples, potassium levels were $1425.900 \pm 3.764 \mathrm{mg} \cdot \mathrm{kg}^{-1}$ for Uduvwoku, $2040.200 \pm$ $9.325 \mathrm{mg} \cdot \mathrm{kg}^{-1}$ for Ekore and $3387.300 \pm 7.458 \mathrm{mg} \cdot \mathrm{kg}^{-1}$ in control sample. The decrease in potassium levels of crude oil contaminated soil was similar to the findings of Onuh et al., [60]. It is postulated that the considerable reduction in the availability of $\mathrm{K}$ cation in the studied soils are due to physical blockages of the exchange site on the organic and clay mineral components by the hydrocarbon residues [61].

Poorer available $\mathrm{P}$ and extractable $\mathrm{K}$ could account for poorer tuber yield and chlorotic observations in the farm at Uduvwoku in comparison to Ekore. Similarly, levels of ortho-phosphate and extractable $\mathrm{K}$ in Oil bean seeds were higher in samples from Ekore in comparison to Uduvwoku. Plants deficient in potassium are unable to utilize nitrogen and water efficiently and are more susceptible to disease [55]. Higher nitrate and ammonium nitrogen concentrations in Oil bean seeds could be attributed to its membership to the legume family so are able to take large amounts of nitrogen [62] from the air and convert it to protein in the seeds.

The 17 EPA Polycyclic Aromatic Hydrocarbons (PAHs) were investigated in the contaminated soils and control, total mean concentrations of PAHs in $\mathrm{mg} \cdot \mathrm{kg}^{-1}$ dry weight of soil, cassava and oil beans and presented in Tables 3-5 respectively. Average individual soil PAHs ranged from BDL to $98.120 \pm 0.012\left(\times 10^{-3} \mathrm{mg} \cdot \mathrm{kg}^{-1}\right) \mathrm{dw}$, BDL to $643.300 \pm 0.116\left(\times 10^{-3} \mathrm{mg} \cdot \mathrm{kg}^{-1}\right) \mathrm{dw}$, and BDL to $1380.000 \pm 1.732\left(\times 10^{-3} \mathrm{mg} \cdot \mathrm{kg}^{-1}\right) \mathrm{dw}$ for Okpe, Ekore and Uduvwoku samples respectively (Table 3). Bioaccumulation distribution showed individual PAHs from BDL to $70.640 \pm 0.006\left(\times 10^{-3} \mathrm{mg} \cdot \mathrm{kg}^{-1}\right) \mathrm{dw}$, BDL to $99.193 \pm 0.026\left(\times 10^{-3} \mathrm{mg} \cdot \mathrm{kg}^{-1}\right) \mathrm{dw}$ and BDL to $614.000 \pm 0.058\left(\times 10^{-3} \mathrm{mg} \cdot \mathrm{kg}^{-1}\right)$ $\mathrm{dw}$ for Okpe, Ekore and Uduvwoku Cassava samples respectively but ranged from BDL to $62.480 \pm 0.006\left(\times 10^{-3} \mathrm{mg} \cdot \mathrm{kg}^{-1}\right) \mathrm{dw}$, BDL to $106.90 \pm 0.05\left(\times 10^{-3} \mathrm{mg} \cdot \mathrm{kg}^{-1}\right) \mathrm{dw}$ and BDL to $105.300 \pm 0.116\left(\times 10^{-3} \mathrm{mg} \cdot \mathrm{kg}^{-1}\right) \mathrm{dw}$ in the same order (Table 4 and Table 5). Of 17 EPA PAHs assessed, the highest mean concentration was recorded for pyrene in soil and Cassava samples irrespective of location. In oil bean samples however, Benzo (k)fluoranthene ranked highest for Okpe and Ekore samples but Indeno(1,2,3-cd)pyrene for Uduvwoku samples. Pyrene is ubiquitous in the environment as a product of incomplete combustion of fossil fuels and has been identified in surface and drinking water, numerous foods, and in ambient air [63] [64]. Despite the large body of literature on the toxicity and carcinogenicity of PAHs, toxicity data for pyrene are limited. TRL [65] reported that sub-chronic oral exposure to pyrene produced nephropathy, decreased kidney weights, increased liver weight and slightly haematological changes in mice while White and White [66] documented produced fatty livers in rats. Yoshikawa et al. [67] asserted that a single intraperitoneal injection of pyrene produced swelling 
Table 3. Mean concentrations of PAHs $\left(\times 10^{-3} \mathrm{mg} \cdot \mathrm{kg}^{-1}\right)$ in soil samples.

\begin{tabular}{cccc}
\hline Contaminants & Okpe & Ekore & Uduvwoku \\
\hline Acenaphthene & BDL & BDL & BDL \\
Acenaphthylene & BDL & BDL & BDL \\
Anthracene & $69.849 \pm 0.001^{\mathrm{a}}$ & $47.530 \pm 0.011^{\mathrm{a}}$ & $134.30 \pm 0.116^{\mathrm{a}}$ \\
Benz(a)anthracene & BDL & $2.564 \pm 0.001^{\mathrm{a}}$ & $99.120 \pm 0.012^{\mathrm{a}}$ \\
Benzo(a)pyrene & $0.862 \pm 0.001^{\mathrm{a}}$ & $9.918 \pm 0.001^{\mathrm{b}}$ & $12.330 \pm 0.012^{\mathrm{b}}$ \\
Benzo(g,h,i)perylene & $21.620 \pm 0.012^{\mathrm{a}}$ & $45.160 \pm 0.116^{\mathrm{a}}$ & $281.400 \pm 0.116^{\mathrm{a}}$ \\
Benzo(b)fluoranthene & $5.140 \pm 0.017^{\mathrm{a}}$ & $61.910 \pm 0.017^{\mathrm{b}}$ & $306.500 \pm 0.056^{\mathrm{b}}$ \\
Benzo(k)fluoranthene & $19.360 \pm 0.012^{\mathrm{a}}$ & $100.200 \pm 0.116^{\mathrm{a}}$ & $623.100 \pm 0.058^{\mathrm{a}}$ \\
Chrysene & $29.380 \pm 0.006^{\mathrm{a}}$ & $19.300 \pm 0.000^{\mathrm{a}}$ & $\mathrm{BDL}$ \\
Dibenz(a,h)anthracene & $31.700 \pm 0.000^{\mathrm{b}}$ & $17.740 \pm 0.012^{\mathrm{a}}$ & $46.070 \pm 0.012^{\mathrm{a}}$ \\
Fluoranthene & $62.450 \pm 0.012^{\mathrm{a}}$ & $68.890 \pm 0.000^{\mathrm{b}}$ & BDL \\
Indeno(1,2,3-cd)pyrene & $41.300 \pm 0.116^{\mathrm{a}}$ & $59.340 \pm 0.006^{\mathrm{a}}$ & $941.500 \pm 0.058^{\mathrm{a}}$ \\
Fluorene & $47.310 \pm 0.006^{\mathrm{a}}$ & $34.480 \pm 0.006^{\mathrm{a}}$ & $323.500 \pm 0.000^{\mathrm{a}}$ \\
Naphthalene & $42.610 \pm 0.006^{\mathrm{a}}$ & $40.800 \pm 0.006^{\mathrm{a}}$ & $204.300 \pm 0.058^{\mathrm{a}}$ \\
2-methylnaphthalene & $44.450 \pm 0.017^{\mathrm{a}}$ & $18.290 \pm 0.017^{\mathrm{a}}$ & $260.900 \pm 0.231^{\mathrm{a}}$ \\
Phenanthrene & $17.510 \pm 0.006^{\mathrm{a}}$ & $2.384 \pm 0.012^{\mathrm{a}}$ & BDL \\
Pyrene & $98.120 \pm 0.012^{\mathrm{a}}$ & $643.300 \pm 0.116^{\mathrm{a}}$ & $1380.000 \pm 1.732^{\mathrm{a}}$ \\
Total & 531.661 & 1261.806 & 4613.020 \\
\hline
\end{tabular}

Values (mean \pm S.E.M), $\mathrm{n}=3$. Means in the same row bearing the same superscript are not significantly different at 95\% level. BDL means below detectable limit.

and congestion of the liver as well as increased serum aspartate amino transferase (AST) and bilirubin levels in rats. U.S. EPA [64] classified Benzo[k]fluoranthene, based on no human data and sufficient data from animal assays, as B2 probable human carcinogen. Benzo[k]fluoranthene produced tumors after lung implantation in mice and when fed with a promoting agent in skin-painting studies and mutagenic in bacteria. U.S. EPA [68] reported that Benzao[k]fluoranthene is a component of mixtures that have been associated with human cancer, despite limited human data specifically linking its exposure to human cancers, and listed these mixtures to include coal tar, soot, coke oven emissions and cigarette smoke.

The total mean PAHs in soil samples from Okpe, Ekore and Uduvwoku were 531.661 $\left(\times 10^{-3} \mathrm{mg} \cdot \mathrm{kg}^{-1}\right) \mathrm{dw}, 1261.806 \mathrm{mg} \cdot \mathrm{kg}^{-1} \mathrm{dw}$ and $4613.020 \mathrm{mg} \cdot \mathrm{kg}^{-1} \mathrm{dw}$ (Table 3). Those in cassava samples were $244.698\left(\times 10^{-3} \mathrm{mg} \cdot \mathrm{kg}^{-1}\right) \mathrm{dw}, 504.013\left(\times 10^{-3} \mathrm{mg} \cdot \mathrm{kg}^{-1}\right) \mathrm{dw}$ and $1001.464\left(\times 10^{-3} \mathrm{mg} \cdot \mathrm{kg}^{-1}\right) \mathrm{dw}$ from Okpe, Ekore and Uduvwoku respectively (Table 4); while $122.318\left(\times 10^{-3} \mathrm{mg} \cdot \mathrm{kg}^{-1}\right) \mathrm{dw}, 446.785\left(\times 10^{-3} \mathrm{mg} \cdot \mathrm{kg}^{-1}\right) \mathrm{dw}$ and $495.815\left(\times 10^{-3}\right.$ $\left.\mathrm{mg} \cdot \mathrm{kg}^{-1}\right) \mathrm{dw}$ were recorded for Oil bean samples from Okpe, Ekore and Uduvwoku respectively (Table 5). Total mean PAHs in soil samples from oil impacted sites (Ekore and Uduvwoku) exceeded Department of Petroleum Resources' permissible limits of $1000 \mu \mathrm{g} \cdot \mathrm{kg}^{-1}$ [69]. The total mean concentration of PAHs in the crop samples exceeded the European Union Limit of $0.2 \mathrm{mg} \cdot \mathrm{kg}^{-1}$ [70]. Similarly, potential danger is inevitable 
Table 4. Mean concentrations of PAHs $\left(\times 10^{-3} \mathrm{mg} \cdot \mathrm{kg}^{-1}\right)$ in cassava samples.

\begin{tabular}{|c|c|c|c|}
\hline Contaminants & Okpe & Ekore & Uduvwoku \\
\hline Acenaphthene & $\mathrm{BDL}$ & $\mathrm{BDL}$ & $\mathrm{BDL}$ \\
\hline Acenaphthylene & $\mathrm{BDL}$ & $\mathrm{BDL}$ & $\mathrm{BDL}$ \\
\hline Anthracene & $2.165 \pm 0.001^{\mathrm{a}}$ & $4.180 \pm 0.001^{c}$ & $2.682 \pm 0.001^{\mathrm{a}}$ \\
\hline Benz(a)anthracene & $\mathrm{BDL}$ & $\mathrm{BDL}$ & $\mathrm{BDL}$ \\
\hline Benzo(a)pyrene & $1.000 \pm 0.581^{\mathrm{a}}$ & $10.110 \pm 0.006^{\mathrm{a}}$ & $10.279 \pm 0.000^{\mathrm{a}}$ \\
\hline Benzo(g,h,i)perylene & $3.530 \pm 0.012^{\mathrm{a}}$ & $32.590 \pm 0.012^{\mathrm{a}}$ & $22.750 \pm 0.017^{\mathrm{a}}$ \\
\hline Benzo(b)fluoranthene & $2.110 \pm 0.006^{\mathrm{a}}$ & $35.500 \pm 0.006^{\mathrm{b}}$ & $22.010 \pm 0.000^{c}$ \\
\hline Benzo(k)fluoranthene & $5.480 \pm 0.006^{\mathrm{a}}$ & $42.330 \pm 0.017^{\mathrm{b}}$ & $68.770 \pm 0.006^{c}$ \\
\hline Chrysene & $20.060 \pm 0.012^{\mathrm{a}}$ & $15.920 \pm 0.012^{\mathrm{a}}$ & $13.980 \pm 0.006^{\mathrm{a}}$ \\
\hline Dibenz(a,h)anthracene & $8.683 \pm 0.001^{\mathrm{a}}$ & $14.710 \pm 0.006^{\mathrm{a}}$ & $14.430 \pm 0.012^{\mathrm{a}}$ \\
\hline Fluoranthene & $\mathrm{BDL}$ & $\mathrm{BDL}$ & $21.310 \pm 0.006^{\mathrm{a}}$ \\
\hline Indeno(1,2,3-cd)pyrene & $7.800 \pm 0.006^{\mathrm{a}}$ & $95.420 \pm 0.012^{\mathrm{a}}$ & $43.410 \pm 0.006^{\mathrm{a}}$ \\
\hline Fluorene & $11.330 \pm 0.006^{\mathrm{a}}$ & $25.680 \pm 0.006^{\mathrm{a}}$ & $35.850 \pm 0.017^{\mathrm{a}}$ \\
\hline Naphthalene & $12.380 \pm 0.012^{\mathrm{a}}$ & $61.480 \pm 0.012^{\mathrm{a}}$ & $77.990 \pm 0.006^{\mathrm{a}}$ \\
\hline 2-methylnaphthalene & $28.880 \pm 0.006^{\mathrm{a}}$ & $56.610 \pm 0.006^{\mathrm{a}}$ & $25.983 \pm 0.343^{\mathrm{a}}$ \\
\hline Phenanthrene & $70.640 \pm 0.006^{\mathrm{a}}$ & $10.290 \pm 0.017^{\mathrm{a}}$ & $28.020 \pm 0.000^{\mathrm{a}}$ \\
\hline Pyrene & $70.640 \pm 0.006^{\mathrm{a}}$ & $99.193 \pm 0.026^{\mathrm{b}}$ & $614.000 \pm 0.058^{c}$ \\
\hline Total & 244.698 & 504.013 & 1001.464 \\
\hline
\end{tabular}

Values (mean \pm S.E.M), $\mathrm{n}=3$. Means in the same row bearing the same superscript are not significantly different at 95\% level. BDL means below detectable limit.

as levels of strongly carcinogenic Benzo(a)pyrene marginally exceeded DPR intervention limit of $0.01 \mathrm{mg} \mathrm{dw} \mathrm{kg} \mathrm{mg} \cdot \mathrm{kg}^{-1}$ for food for Cassava (Uduvwoku and Ekore) and Oil bean (Uduvwoku only) samples. Because of the very low water solubility, PAH will tend to be sorbed to the organic matter in the soil instead of being solubilised in the infiltrating water and through this, it may be transported downwards to the ground water.

IARC [64] identified Fluoranthene in ambient air, surface, drinking, and waste water, and in char-broiled foods. According to U.S. EPA [68], Fluoranthene would be expected to be absorbed from the gastrointestinal tract and lungs by analogy to structurally-related PAHs, and can be absorbed through the skin following dermal exposure. They also reported that sub-chronic oral exposure to fluoranthene at doses $\geq 250$ $\mathrm{mg} \cdot \mathrm{kg}^{-1}$ produced nephropathy, increased liver weights, and increased liver enzyme levels in rats. La Gomes and Liteplo [71] described an in vitro study identified 2methylfluoranthene and 3-methylfluoranthene and their dihydrodiols as metabolites of fluoranthene. Given limited or no data from animal or human bioassays to assess the carcinogenicity of fluoranthene, U.S. EPA [63] placed fluoranthene in weight-ofevidence group D, not classifiable as to human carcinogenicity.

The very low molecular weight PAHs such as acenaphthalene and acenaphthene were not detected probably due to high volatilization or dissolution which may have 
Table 5. Mean concentrations of PAHs $\left(\times 10^{-3} \mathrm{mg} \cdot \mathrm{kg}^{-1}\right)$ in oil bean samples.

\begin{tabular}{|c|c|c|c|}
\hline Contaminants & Okpe & Ekore & Uduvwoku \\
\hline Acenaphthene & $\mathrm{BDL}$ & $\mathrm{BDL}$ & $\mathrm{BDL}$ \\
\hline Acenaphthylene & $\mathrm{BDL}$ & $\mathrm{BDL}$ & $\mathrm{BDL}$ \\
\hline Anthracene & $3.274 \pm 0.001^{\mathrm{a}}$ & $4.86 \pm 0.001^{\mathrm{c}}$ & $6.907 \pm 0.001^{\mathrm{a}}$ \\
\hline Benz(a)anthracene & $\mathrm{BDL}$ & $\mathrm{BDL}$ & $\mathrm{BDL}$ \\
\hline Benzo(a)pyrene & $0.894 \pm 0.001^{\mathrm{a}}$ & $1.665 \pm 0.001^{\mathrm{a}}$ & $12.330 \pm 0.012^{\mathrm{a}}$ \\
\hline Benzo(g,h,i)perylene & $1.620 \pm 0.006^{\mathrm{a}}$ & $37.980 \pm 0.006^{\mathrm{a}}$ & $35.860 \pm 0.012^{\mathrm{a}}$ \\
\hline Benzo(b)fluoranthene & $1.610 \pm 0.006^{\mathrm{a}}$ & $50.120 \pm 0.012^{\mathrm{b}}$ & $27.180 \pm 0.012^{\mathrm{a}}$ \\
\hline Benzo(k)fluoranthene & $12.480 \pm 0.006^{\mathrm{a}}$ & $106.90 \pm 0.05^{\mathrm{b}}$ & $78.300 \pm 0.017^{\mathrm{c}}$ \\
\hline Chrysene & $10.840 \pm 0.012^{\mathrm{a}}$ & $26.320 \pm 0.012^{\mathrm{a}}$ & $22.030 \pm 0.012^{\mathrm{a}}$ \\
\hline Dibenz(a,h)anthracene & $11.060 \pm 0.017^{\mathrm{a}}$ & $24.740 \pm 0.006^{\mathrm{a}}$ & $28.240 \pm 0.012^{\mathrm{a}}$ \\
\hline Fluoranthene & $15.860 \pm 0.012^{\mathrm{a}}$ & $36.980 \pm 0.006^{c}$ & $21.870 \pm 0.012^{\mathrm{b}}$ \\
\hline Indeno(1,2,3-cd)pyrene & $5.530 \pm 0.006^{\mathrm{a}}$ & $14.540 \pm 0.023^{\mathrm{a}}$ & $105.300 \pm 0.116^{\mathrm{a}}$ \\
\hline Fluorene & $11.150 \pm 0.006^{\mathrm{a}}$ & $75.130 \pm 0.012^{\mathrm{a}}$ & $37.250 \pm 0.006^{\mathrm{a}}$ \\
\hline Naphthalene & $12.140 \pm 0.006^{\mathrm{a}}$ & $25.550 \pm 0.006^{\mathrm{a}}$ & $42.950 \pm 0.006^{\mathrm{a}}$ \\
\hline 2-methylnaphthalene & $23.260 \pm 0.017^{\mathrm{a}}$ & $13.240 \pm 0.012^{\mathrm{a}}$ & $29.220 \pm 0.012^{\mathrm{a}}$ \\
\hline Phenanthrene & $\mathrm{BDL}$ & $16.160 \pm 0.0129^{\mathrm{a}}$ & $24.238 \pm 0.000^{\mathrm{a}}$ \\
\hline Pyrene & $12.600 \pm 0.012^{\mathrm{a}}$ & $12.600 \pm 33.333^{\mathrm{a}}$ & $24.140 \pm 0.012^{\mathrm{a}}$ \\
\hline Total & 122.318 & 446.785 & 495.815 \\
\hline
\end{tabular}

Values (mean \pm S.E.M), $\mathrm{n}=3$. Means in the same row bearing the same superscript are not significantly different at $95 \%$ level. BDL means below detectable limit.

occurred during the process of extraction. It may also be due to the length time of exposure of the soil samples prior to this study. The results of the concentrations $\left(\mathrm{mg} \cdot \mathrm{kg}^{-1}\right)$ of the PAHs investigated in test soils indicated the presence of benzo[k]fluoranthene, benzo[b]fluoranthene, pyrene and indeno[1,2,3-cd]pyrene. Benzo[b]fluoranthene PAH constitutes one of the largest group of compounds with high concentrations in a typical soil sample contaminated with PAHs. From the results, it is evident that the soils of the study sites were contaminated with PAHs at varying concentrations. However, the total PAHs concentrations were very low when compared with the maximum background limits of $15 \mathrm{mg} \cdot \mathrm{kg}^{-1}$ in polluted soils set by Dutch and Polish Environment Ministries respectively [72].

These low values recorded should not be taken for granted; since there is no threshold concentration below which carcinogenic effects of PAH does not occur. Six (6) components of the PAHs (benzo[a]anthracene, chrysene, benzo[b]fluoranthrene, indeno[1,3-c,d]pyrene, dibenz[a,h]anthracene and benzo[k]fluoranthene) detected fall within the category of PAHs with the highest risk especially at prolonged exposure [42]. Four (4) out of the six PAHs namely benzo[a]anthracene, chrysene, benzo[b]fluoranthene and benzo[k]fluoranthene are implicated in carcinogenesis according to the Cal-EPA [73]. Consequently, it is feared that the population of people living in and around the study sites (oil spill sites) may be predisposed to high risk of cancer due to 
long exposure to $\mathrm{PAH}$ compound through contaminated soil and food crops.

The health effects of PAHs have been reviewed extensively. These effects depend mainly on the extent of exposure, dose, innate toxicity and exposure routes [74]. Preexisting health status and age are other predisposing factors. There is risk of harm in both short and long term exposure. Luch [75] reported associated low IQ (intelligent quotient), childhood asthma, premature delivery, low birth weight, heart malfunction, DNA damages in children linked to cancer at high pre-natal exposure to PAHs.

PAHs are ubiquitous in both urban and rural environment and as a result, it is very common to detect at low soils levels and its toxicity consideration is of utmost importance. Emphasizing of posed threats, Villeneuve et al. [76] showed that heavy PAHs can induce dioxin-like activity and weakened estrogenic responses.

PAHs are classified into two broad groups based on physical and biological properties and include high molecular weight (HMW) and low molecular weight (LMW) PAHs. HMW PAHs consists of $4-6$ aromatic rings and are less readily biodegraded by indigenous microorganisms, hence can persist in the aqueous environment by bio-accumulating in aquatic organisms like fish and mussels, and are more carcinogenic [77]. Brown and Peake [78] reported that LMW PAHs consists of 2 - 3 aromatic rings and although less carcinogenic also pose toxic effects to many aquatic organisms. Distribution of LMW (Figure 1) and HMW (Figure 2) PAHs in this study revealed mean soil, Cassava and Oil bean LMW PAHs of 221.729, 143.484 and $923\left(\times 10^{-3} \mathrm{mg} \cdot \mathrm{kg}^{-1}\right) \mathrm{dw}$; $125.395,158.24$; and $170.525\left(\times 10^{-3} \mathrm{mg} \cdot \mathrm{kg}^{-1}\right) \mathrm{dw}$ and $49.824,134.94$ and $140.565\left(\times 10^{-3}\right.$ $\left.\mathrm{mg} \cdot \mathrm{kg}^{-1}\right) \mathrm{dw}$ for Okpe, Ekore and Uduvwoku respectively. In the same vein, HMW PAHs gave mean soil, Cassava and Oil bean levels of 309.932, 1028.322 and 3690.02 $\left(\times 10^{-3} \mathrm{mg} \cdot \mathrm{kg}^{-1}\right) \mathrm{dw} ; 119.303,345.773$ and $830.939\left(\times 10^{-3} \mathrm{mg} \cdot \mathrm{kg}^{-1}\right) \mathrm{dw}$; and 72.494, 311.845 and $355.25\left(\times 10^{-3} \mathrm{mg} \cdot \mathrm{kg}^{-1}\right) \mathrm{dw}$ for Okpe, Ekore and Uduvwoku respectively. Okpe may have been contaminated with naturally occurring PAHs (petrogenic and biogenic origins) hence elevated levels of LMH PAHs. Those for Uduvwoku was significantly higher for soil samples studied (Figure 1). Markedly higher HMW PAHs in Uduvwoku samples is suggestive of pyrolytic PAHs origin and implicate the site over

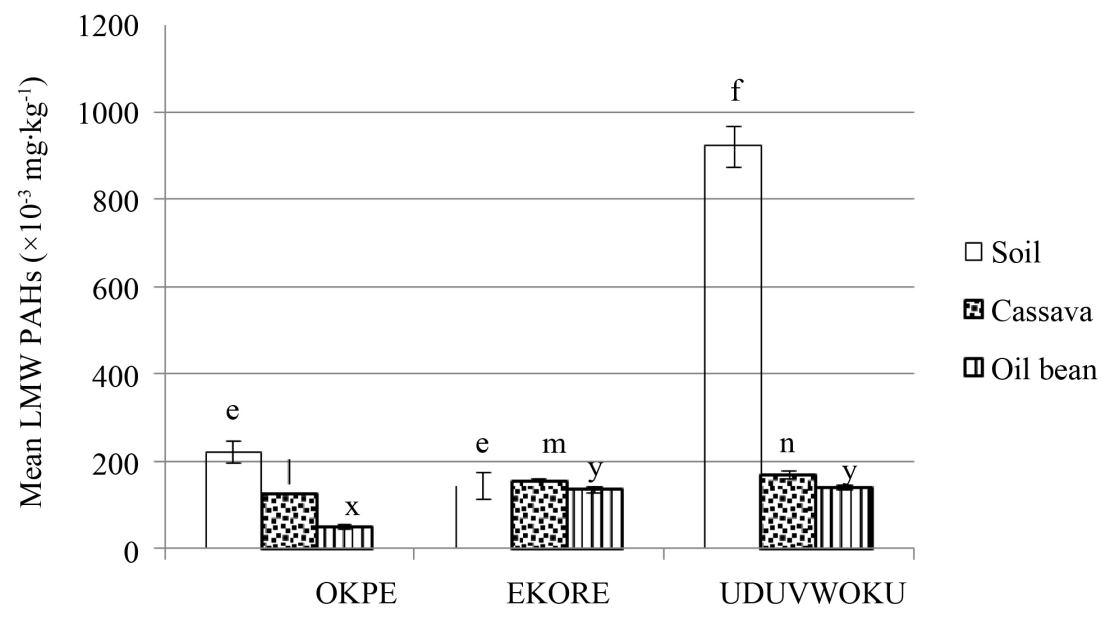

Figure 1. Mean distribution of Low molecular weight (LMW) PAHs in study samples. 


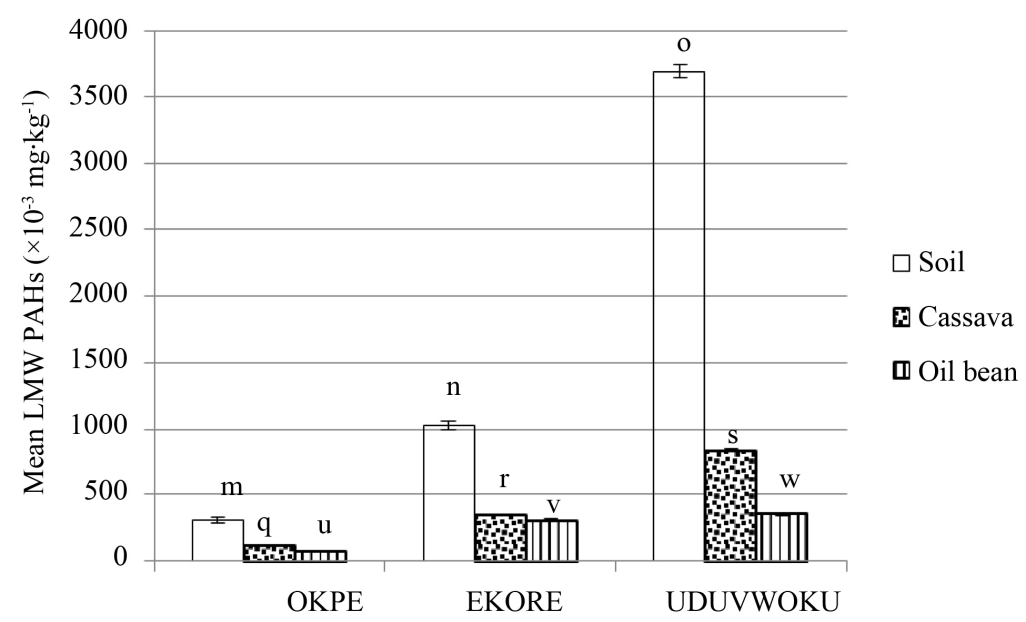

Figure 2. Mean distribution of High molecular weight (HMW) PAHs in study samples.

Ekore in terms of more enduring risks implied with less biodegradation of aromatic rings. Of the most cultivated food crops studied, Cassava, one of Nigeria' most staple food is highly implicated in bioaccumulation of recalcitrant and more carcinogenic HMW PAHs.

\section{Conclusion}

From the results of this study, it is evident that oil exploration and production activities (and oil spillages) variably degraded the soil where such activities are carried out. The study has demonstrated that crude oil contamination can lead to gradual heavy metal and PAHs build up in plants growing in such soils as up to $0.413 \mathrm{mg} \cdot \mathrm{kg}^{-1}$ of Cadmium is found in Oilbean harvested from impacted site. Besides recorded nutrient loss, real effect of spill on soil in terms of soil fertility may have been cushioned by agricultural activities and could be worse on inactive soils. The plants studied were highly vulnerable, suggesting that the site poses potential hazards to grazing animals, humans and the food chain. There is, therefore the urgent need for remediation processes or strategies and management of the contaminated soils, so as to render it fit for use especially for agricultural and domestic purposes. Data generated from study soil testing could inform degree of contamination, efficient and effective resource management of Ekore and Uduvwoku farmlands.

\section{Acknowledgements}

The authors will like to acknowledge Okonkwo, I. C. for assistance in data acquisition.

\section{References}

[1] Ekanem, S. A, Ejue, B., Amimi, P.B. and Adalikwu, R.A. (2010) Living with Oil: Towards an Ethics of the Environment in the Niger Delta. African Research Review, 4, 17-30. http://dx.doi.org/10.4314/afrrev.v4i3.60140

[2] Onyenekenwa, C.E. (2011) A Review on Petroleum: Sources, Uses, Processing, Products 
and the Environments. Journal of Applied Science, 11, 2084-2091.

http://dx.doi.org/10.3923/jas.2011.2084.2091

[3] Nwaichi, E.O. (2014) Environmental Impacts and Prospects of Petroleum Production: A Case Study of the Niger Delta. In: Daniels, J.A., Eds., Advances in Environmental Research, Vol. 35, Chapter 7, Nova Science Publishers Inc., New York, 173-188.

[4] Worgu, C.A. (2000) Heavy Metal Concentration in Some Seafood Commonly Consumed in Selected Parts of River State. Journal of Applied Chemistry and Agricultural Research, 2, 44-47.

[5] United Nations Development Programme (UNDP) (2006) Niger Delta Human Development Report, Abuja.

[6] Nwaichi, E.O. and Uzazobona, M.A. (2011) Estimation of the $\mathrm{CO}_{2}$ Level Due to Gas Flaring in the Niger Delta. Research Journal of Environmental Sciences, 5, 565-572. http://dx.doi.org/10.3923/rjes.2011.565.572

[7] Abii, T.A. and Nwosu, P.C. (2009) The Effect of Oil-Spillage on the Soil of Eleme in Rivers State of the Niger-Delta area of Nigeria. Research Journal of Environmental Sciences, 3, 316-320. http://dx.doi.org/10.3923/rjes.2009.316.320

[8] Ogbu, A. (2008) Nigerian: Militants Hit Pipelines Again. World Prout Assembly, Lagos, 22 April 2008.

[9] Nwuche, C.O. and Ugorji, E.O. (2010) Effect of Co-Existing Plant Species on Soil Microbial Activity under Heavy Metal Stress. International Journal on Environmental Science and Technology, 7, 697-704. http://dx.doi.org/10.1007/BF03326179

[10] Duru, P.O. (2005) Impact of Oil Spillage on Soils in Some Oil Producing Communities of Imo State. Unpublished Doctoral Dissertation, Imo State University, Owerri, 238.

[11] Otitoloju, A.A. and Udosen, U.M. (2004) Observation of Synergistic Interactions in Mixtures of Crude Oil and Dispersants Tested against Earthworm (Eudrilus eugeniae). Journal of Nigerian Environment Society, 2, 163-168.

[12] Daniel-Kalio, L.A. and Braide, S.A. (2004) The Effects of Oil Spillage on a Cultivated Wetland of the Niger Delta. Journal of Environmental Sciences, 2, 153-158.

[13] Nwaichi, E.O., Wegwu, M.O. and Nwosu, U.L. (2014) Distribution of Selected Carcinogenic Hydrocarbon and Heavy Metals in an Oil-Polluted Agriculture Zone. Environmental Monitoring and Assessment, 186, 8697-8706. http://dx.doi.org/10.1007/s10661-014-4037-6

[14] Mckelvey, W., Charon, G.R. and Jeffery, N. (2007) A Biomonitoring Study of Lead, Cadmium and Mercury in the Blood of New York City Adults. Environmental Health Perspective, 115, 1435-1441. http://dx.doi.org/10.1289/ehp.10056

[15] Palese, A.M., Giovamini, G., Luches, S. and Perucei, P. (2003) Effect of Fire on Soil Carbon, Nitrogen and Microbial Biomass. Agronomite, 24, 47-53. http://dx.doi.org/10.1051/agro:2003061

[16] Nkwocha, E.E. and Duru, P.O. (2010) Micro-Analytic Study on the Effect of Oil Pollution on Local Plant Species and Food Crops. Advances in Bioresearch, 1, 189-198.

[17] Nwaichi, E.O., Onyeike, E.N. and Wegwu, M.O. (2010) Characterization and Safety Evaluation of the Impact of Hydrocarbons Contaminants on Ecological Receptors. Bulletin of Environmental Contamination and Toxicology, 85, 199-204. http://dx.doi.org/10.1007/s00128-010-0062-5

[18] Kalili, A., Ebadi, T., Rabbani, A. and Sadri, M.S. (2011) Response Surface Methodology Approach to the Optimization of Oil Hydrocarbon Polluted Soil Remediation Using Enhanced Soil Washing. International Journal on Environmental Science and Technology, 8, 389-400. http://dx.doi.org/10.1007/BF03326226 
[19] Costa, M. and Klein, C.B. (2006) Toxicity and Carcinogencity of Chromium Compounds in Humans. Critical Reviews in Toxicology, 36, 155-163. http://dx.doi.org/10.1080/10408440500534032

[20] Luo, W.H., Yuan-Zhang, Y. and Li, H. (2003) Children's Blood Lead Levels after the Phasing out of Leaded Gasoline in Shantou, China. Archives of Environmental Health, 58, 184-187. http://dx.doi.org/10.3200/AEOH.58.3.184-187

[21] Doll, R. (1996) Nature and Nurture: Possibilities for Cancer Control. Carcinogenesis, 17, 177-184. http://dx.doi.org/10.1093/carcin/17.2.177

[22] Ferner, D.J. (2001) Toxicity of Heavy Metals. eMedicine Journal, 2, 1.

[23] Pippah, O.J. (1999) Urhobo Almanac. Crabs Publication, Lagos.

[24] Khan, S., Cao, Q., Zheng, Y.M., Huang, Y.Z. and Zhu, Y.G. (2008) Health Risks of Heavy Metals in Contaminated Soils and Food Crops Irrigated with Wastewater in Beijing, China. Environmental Pollution, 152, 686-692. http://dx.doi.org/10.1016/j.envpol.2007.06.056

[25] API (American Petroleum Institute) (1994) Inter Laboratory Study of Three Methods for Analyzing Petroleum Hydrocarbons in Soil, Diesel Range Organics (DRO), Gasoline Range Organics (GRO) and Petroleum Hydrocarbon (PHC). Publication Number 4599.

[26] World Health Organization (1985) Guidelines for the Study of Dietary Intake of Chemical Contaminants. WHO Offset Publication, No. 87, WHO, Geneva.

[27] EFSA (2009) European Food Safety Authority. http://www.efsa.europa.eu/en/press/news/contam090320

[28] Pinto, A.P., Mota, A.M., de Varennes, A. and Pinto, F.C. (2004) Influence of Organic Matter on the Uptake of Cadmium, Zinc, Copper and Iron by Sorghum Plants. Science of the Total Environment, 326, 239-247. http://dx.doi.org/10.1016/j.scitotenv.2004.01.004

[29] Lichtfouse E. (2009) Organic Farming, Pest Control and Remediation of Soil Pollutants. Springer Science \& Business Media, Berlin.

[30] Sandalo, L.C., Dalurzo, H.C. and Gomez, M. (2001) Cadmium Induces Changes in the Growth and Oxidative Metabolism of Pea Plants. Journal of Experimental Botany, 52, 21152126.

[31] Goyer, R.A. and Clarkson, T.W. (2001) Toxic Effects of Metals. In: Klaasen, C.D., Ed., Casarett and Doullis Toxicology: The Basic Science of Poisons, 6th Edition, McGraw-Hill, New York, 861-867.

[32] Nogawa, K., Honda, R., Kido, T., Tsuritani, I. and Yamanda, Y. (1987) Limits to Protect People Eating Cadmium in Rice, Based on Epidemiological Studies. Trace Substance Environmental Health, 21, 431-439

[33] Alloway, B.J. (1995) Cadmium. In: Alloway, B.J., Ed., Heavy Metals in Soils, 2nd Edition, Blackie, New York, 122-151.

[34] Forstner, U. (1995) Land Contamination by Metals: Global Scope and Magnitude of Problem. In: Allen, H.E., Huang, C.P., Bailey, G.W. and Bowers, A.R., Eds., Metal Speciation and Contamination of Soil, CRC Press, Boca Raton, 1-33.

[35] Wolfgang, M. and Jean-Marc, M. (2013) The Bioinorganic Chemistry of Cadmium in the Context of its Toxicity. In: Sigel, A., Sigel, H. and Sigel, R.K.O., Eds., Cadmium: From Toxicology to Essentiality, Metal Ions in Life Sciences 11, Chapter 1, Sprnger, Berlin, 1-30.

[36] Mench, M., Didier, V., Löffler, M., Gomez, A. and Masson, P. (1994) A Mimicked In-Situ Remediation Study of Metal-Contaminated Soils with Emphasis on Cadmium and Lead. Journal on Environmental Quality, 23, 58-63. http://dx.doi.org/10.2134/jeq1994.00472425002300010010x 
[37] Chirenje, T., Ma, L., Reeves, M. and Szulezewski, M. (2004) Lead Distribution in NearSurface Soils of Two Florida Cities: Gainesville and Miami. Geoderma, 119, 113-120. http://dx.doi.org/10.1016/S0016-7061(03)00244-1

[38] Onweremadu, E.U. and Duriugbo, C.I. (2007) Assessment of Cadmium Concentration of Crude Oil Pollution on Arable Soil. International Journal of Environmental Science and Technology, 4, 409-412. http://dx.doi.org/10.1007/BF03326300

[39] Goyer, R.A. and Cherian, M.G. (1992) Role of Metalloprotein in Human Placenta and Rat Exposed to Cadmium. Cadmium in the Human Environment, Toxicity and Carcinogenicity, 7, 239-247.

[40] Food and Agriculture Organization/World Health Organization (FAO/WHO) (1984) Energy and Protein Requirements. Report of a Joint FAO/WHO Ad Hoc Expert Committee.

[41] Costa, M. and Klein, C.B. (2006) Toxicity and Carcinogenicity of Chromium Compounds in Humans. Critical Reviews in Toxicology, 36, 155-163. http://dx.doi.org/10.1080/10408440500534032

[42] ATSDR (2007) Agency for Toxic Substances and Disease Registry. Toxicological Profile for Lead, US Department of Health and Human Services, Atlanta.

[43] Asia, I.O., Jegede, S.I., Jegede, D.A., Ize-Iyamu, O.K. and Akpasubi, E.B. (2007) The Effects of Petroleum Exploration and Production Operations on the heavy Metals Contents of Soils and Groundwater in the Niger Delta. International Journal of Physical Sciences, 2, 271-275.

[44] Kosolapov, D.B., Kuschk, P., Vainshtein, M.B., Vatsourina, A. ., Wiebner, A., Kasterner, M. and Miler, R.A. (2004) Microbial Processes of Heavy Metal Removal from Carbon Deficient Effluents in Constructed Wetlands. English Life Science, 4, 403-411. http://dx.doi.org/10.1002/elsc.200420048

[45] World Health Organization (1973) Trace Element in Human Nutrition. WHO Technical Report Series, No. 532, WHO, Geneva.

[46] Bjuhr, J. (2007) Trace Metals in Soils Irrigated with Waste Water in a Periuruban Area Downstream Hanoi City, Vietnam. Seminar Paper, Institution for Narkvetenskap, Sveriges Lantbruks Universitet (SLU), Uppsala, Sweden.

[47] Bowen, H.J.M. (1979) Environmental Chemical of the Element. Academic Press, London, 79.

[48] Idodo-Umeh, G. (2002) Water Quality Assessment of Water Bodies in Olomoro, Isoko South, Delta State, Nigeria, using Physical, Chemical and Biological Indices. Doctoral Thesis, University of Benin, Benin.

[49] Baker, K.H. and Henson, S.D. (1994) Bioremediation. McGraw-Hill, New York.

[50] Okolo, J.C., Amadi, E.N., Odu and C.T.I. (2005) Effects of Soil Treatments Containing Poultry Manure on Crude Oil Degradation in a Sandy Loam Soil. Applied Biology and Environmental Research, 3, 47-53. http://dx.doi.org/10.15666/aeer/0301_047053

[51] Onuoha, C.I., Arinze, A.E. and Ataga, A.E. (2003) Evaluation of Growth of Some Fungi in Crude Oil Polluted Environment. Global Journal of Agricultural Science, 2, 1596-2903.

[52] Nwaichi, E.O. and Wegwu, M.O. (2012) Nutrient Profile of a Contaminated Soil Phytoremediated by Centrosema pubescen and Mucuna pruriens. Bioremediation, 12, 212-217. http://dx.doi.org/10.1080/10889868.2012.703259

[53] Food and Agriculture Organization (FAO) (2002) World Agriculture: Towards 2015/2030. Summary Report, Rome.

[54] Fulton, A., County, G., County, C. and County, S. (2010) Primary Plant Nutrients: Nitrogen, Phosphorus, and Potassium. 
http://cetehama.ucanr.edu/newsletters/Soil_Testing_Articles-by_Allan_Fulton39345.pdf

[55] UMass (2016) University of Massachusetts Amherst. Interpreting Your Soil Test Results. https://soiltest.umass.edu/fact-sheets/interpreting-your-soil-test-results

[56] Odu, C.T.I., Nwoboshi, L.C. and Esuruoso, O.F. (1985) Environmental Studies (Soils and Vegetation) of the Nigerian Agip Oil Company Operation Areas. Proceedings of the International Seminar on the Petroleum Industry and the Nigerian Environment, Lagos, 274-283.

[57] Jobson, A., McLaughlin, M., Cook, F.D. and Westlake, D.W.S. (1974) Effects of Amendments the Microbial Utilization of Oil Applied to Soil. Applied Microbiology, 27, 166-171.

[58] Debojit, B., Jitu, B. and Sarada K.S. (2007) Certain Physic-Chemical Charges in the Soil Brought about by Contamination of Crude Oil in Two Oil Fields of Assam, NE India. European Journal of Experimental Biology, 1, 154-161.

[59] Udo, E.J. (1995) The Effect of Oil Pollution on Soil Germination, Growth and Nutrient Uptake of Corn. Journal of Environmental Quality, 4, 537-540.

http://dx.doi.org/10.2134/jeq1975.00472425000400040023x

[60] Onuh, M.O., Madukwe, D.K. and Ohia, G.U. (2008) Effect of Poultry Manure and Cow Dung on the Physical and Chemical Properties of Crude Oil Polluted Soil. Science World Journal, 3, 45-50.

[61] Gersper, P.L., Arkley, R.J., Glauser, R. and Flint, P.S. (1974) Chemical and Physical Soil Properties and Their Seasonal Dynamics at the Barrow Intensive Site. United States Tundra Biome Data Report, 89.

[62] Martens, J.T. and Entz, M. (2011) Integrating Green Manure and Grazing Systems: A Review. Canadian Journal of Plant Science, 91, 811-824. http://dx.doi.org/10.4141/cjps10177

[63] US EPA (US Environmental Protection Agency) (1993) Health Assessment Summary Tables. Annual FY-93. Prepared by the Office of Health and Environmental Assessment, Environmental Criteria and Assessment Office, Cincinnati, $\mathrm{OH}$, for the Office of Emergency and Remedial Response, Washington DC.

[64] IARC (International Agency for Research on Cancer) (1983) IARC Monographs on the Evaluation of Carcinogenic Risks to Humans. In: Polynuclear Aromatic Compounds, Part 1: Chemical, Environmental and Experimental Data, Vol. 32, World Health Organization, Lyon, 431-445.

[65] TRL (Toxicity Research Laboratories) (1989) 13-Week Mouse Oral Subchronic Toxicity Study. TRL Study No. 042-012. Toxicity Research Laboratories Ltd., Muskegon.

[66] White, J. and White, A. (1939) Inhibition of Growth of the Rat by Oral Administration of Methylcholanthrene, Benzpyrene, or Pyrene and the Effects of Various Dietary Supplements. Journal of Biological Chemistry, 131, 149-161.

[67] Yoshikawa, T., Ruhr, L.P., Flory, W., et al. (1985) Toxicity of Polycyclic Aromatic Hydrocarbons. I. Effect of Phenanthrene, Pyrene and Their Ozonized Products on Blood Chemistry in Rats. Toxicology and Applied Pharmacology, 79, 218-226. http://dx.doi.org/10.1016/0041-008X(85)90343-6

[68] US EPA (US Environmental Protection Agency) (1988) 13-Week Mouse Oral Subchronic Toxicity Study. Prepared by Toxicity Research Laboratories Limited, Muskegon, MI, for the Office of Solid Wastes, Washington DC.

[69] DPR. (1999) Department of Petroleum Resources. Environmental Guidelines and Standards for the Petroleum Industry in Nigeria, Ministry of Petroleum Resources, Lagos.

[70] BFR (2010) Bundesinstitut für Risikobewertung. Federal Institute for Risk Assessment. 
Dossier Submitted by Germany for Carcinogenic PAH in Consumer Products. www.bfr.bund.de

[71] Gomes, R. and Liteplo, R. (1998) Environmental Health Criteria. WHO Task Group on Environmental Health Criteria for Selected Chloroalkyl Ethers. WHO Publication, 30-87.

[72] Polish Environment Ministry (2002) Quality Standards for Soils Due to a Particular PAH content. No. 165, 135.

[73] Cal-EPA (1994) California Environmental Protection Agency.. Memorandum, to Cal/EPA Departments, Boards, and Offices from Standards and Criteria Work Group, Office of Environmental Health Hazard Assessment. California Cancer Potency Factors. In: $\mathrm{A} \mathrm{Me}$ thodology for Using Background PAHs to Support Remediation Decisions, Environ Corporation Emeryville, California, 32.

[74] Obini, U., Afiukwa, J.N. and Okafor, C.O. (2013) Determination of Levels of Polycyclic Aromatic Hydrocarbons in Soil Contaminated with Spent Motor Engine Oil in Abakaliki Auto-Mechanic Village. Journal of Applied Sciences and Environmental Management, 17, 169-175. http://dx.doi.org/10.4314/jasem.v17i2.1

[75] Luch, A. (2005) The Carcinogenic Effects of Polycyclic Aromatic Hydrocarbons. Imperial College Press, London, 21. http://dx.doi.org/10.1142/p306

[76] Villeneuve, D.L., Khim, J.S., Kannan, K. and Giesy, J.P. (2002) Relative Potencies of Individual Polycyclic Aromatic Hydrocarbons to Induce Dioxin-Like and Estrogenic Responses in Three Cell Lines. Environmental Toxicology, 17, 128-137. http://dx.doi.org/10.1002/tox.10041

[77] Rocher, V., Azimi, S., Moilleron, R. and Chebbo, G. (2004) Hydrocarbons and Heavy Metals in the Different Sewer Deposits in the "LeMarais" Catchment (Paris, France): Stocks, Distributions and Origins. Science of the Total Environment, 323, 107-122. http://dx.doi.org/10.1016/j.scitotenv.2003.10.010

[78] Brown, J. and Peake, B. (2006) Sources of Heavy Metals and Polycyclic Aromatic Hydrocarbons in Urban Storm Water Runoff. Science and Total Environment, 359, 145-155. http://dx.doi.org/10.1016/j.scitotenv.2005.05.016

Submit or recommend next manuscript to SCIRP and we will provide best service for you:

Accepting pre-submission inquiries through Email, Facebook, LinkedIn, Twitter, etc.

A wide selection of journals (inclusive of 9 subjects, more than 200 journals)

Providing 24-hour high-quality service

User-friendly online submission system

Fair and swift peer-review system

Efficient typesetting and proofreading procedure

Display of the result of downloads and visits, as well as the number of cited articles

Maximum dissemination of your research work

Submit your manuscript at: http://papersubmission.scirp.org/

Or contact jep@scirp.org 